\title{
EVIDENCE AND THE NEW FEDERAL RULES OF CIVIL PROCEDURE
}

\author{
CHARLES C. CALLAHAN AND EDWIN E. FERGUSON†
}

THE authority given to the United States Supreme Court by the Act of June $19,1934,{ }^{1}$ to prescribe uniform rules of procedure for federal civil actions at law and to unite the federal law and equity practices aptly was said, to afford "an unusual opportunity for introducing effective measures of reform in law administration into our most extended court system and of developing a procedure which may properly be a model to all the states." 2 That the Court intends to avail itself of this opportunity is evidenced both by its decision to proceed "with the preparation of a unified system of rules for cases in equity and actions at law," rather than to limit the rules to common-law cases, as it might have done under the act, and by its appointment of an advisory committee to assist in this undertaking. ${ }^{3}$ There can be no thoroughly effective reform in law administration, however, without an adequate treatment of the matter of evidence. In the application of proper rules of law to the substantive interests involved in litigation, rules of evidence which aid or hamper a court in its investigation of a fact situation, depending upon the character of the rules, are as important as the rules which govern the litigation prior and subsequent to the trial. Modern and liberal rules covering the commencement of an action, pleading, parties, judgments, provisional and final remedies and appellate procedure will be small solace to a party who finds a meritorious case thwarted by a rule of evidence of medieval origin and doubtful merit. These considerations seem particularly applicable to the law of evidence as applied in the federal courts, which, as Dean Dobie, now a member of the Advisory Committee, has put it, is in a state of "veritable hodgepodge." It is proposed in this article to review the general theory and statutory regulation of evidence in federal equity, admiralty, criminal and common-law cases; to discuss the scope of the rule-making power, conformity vs. uniformity, and finally the trend and scope which federal rules of evidence might reasonably take and occupy.

tSterling Fellows, Yale School of Law; members of the Ohio and Iowa bars, respectively. 1. 48 StaT. 1064, 28 U. S. C. A. \$§ 723b, 723c (1934).

2. Clark and Moore, A New Federal Civil Procedure, I, The Backgrotnd (1935) 44 YALE L. J. 387.

3. Address of Chief Justice Hughes before the American Law Institute, May 9, 1935, 55 Sup. Ct. XXXV, XXXVIII, XXXIX; 2 U. S. L. Week, May 14, 1935, at 866, 880.

4. Dobie, Federat Procedure (1928) 623. 


\section{Federat Rules of Evidence}

Are the federal courts bound to follow the law of evidence of the state in which they are sitting in equity or admiralty? In criminal trials? In common-law cases? And, if so, is such conformity limited to the statutory law of the state or does it extend to the law of evidence set out in the decisions of the state courts?

In attempting to answer questions regarding the federal law of evidence, the courts and attorneys have received slight assistance from the statutes. Investigation and resulting confusion have centered about three so-called "conformity" statutes, R. S. 858, the "Competency of Witnesses Act," R.S. 721, the "Rules of Decisions Act," and R.S. 914, the "Conformity Act."

The first of these, R. S. 858 , provides: ${ }^{5}$

"The competency of a witness to testify in any civil action, suit or proceeding in the courts of the United States shall be determined by the law of the state or territory in which the court is held."

The Rules of Decisions Act, which goes back to the first Judiciary Act of 1789 , is as follows: ${ }^{6}$

"The laws of the several states, except where the Constitution, treaties, or statutes of the United States otherwise require or provide, shall be regarded as rules of decision in trials at common law, in the courts of the United States, in cases where they apply."

The third statute, commonly known as the Conformity Act, requires conformity "as near as may be" to the practice, pleadings, and forms and modes of proceedings of the state courts in civil cases, other than in equity and admiralty. ${ }^{7}$

The somewhat ambiguous wording of these statutes, coupled with the delicate policy involved in adjusting the federal judiciary to state systems of procedure and substantive law, has made them the basis of hundreds of decisions and subjected them to a myriad of interpretations, a great many centering around their application to some part of the law of evidence.

5. 34 STAT. 618 (1906), 28 U. S. C. A. $\$ 631$ (1926).

6. U. S. Rev. StaT. $\S 721$ (1878), 28 U. S. C. A. $\S 725$ (1926), derived from 1 Stat. 92 (1789).

7. "The practice, pleadings and forms and modes of proceeding in civil causes, other than equity and admiralty causes, in the district courts, shall conform, as near as may be, to the practice, pleadings, and forms and modes of proceeding existing at the time in like causes in the courts of record of the State within which such district courts are beld, any rule of court to the contrary notwithstanding." U. S. Rev. STar. $\$ 914$ (1878), 28 U. S. C. A. $\S 724$ (1926), derived from 17 STAT. 197 (1872). 


\section{Equity and Admiralty}

Two of the principal conformity statutes have no application in equity or admiralty. The so-called Conformity Act expressly excludes equity and admiralty causes from its operation and the expression, "trials at common law," in the Rules of Decisions Act has been confined, of course, to cases on the law side of the court. ${ }^{8}$ The Competency of Witnesses Act does, however, apply both to equity and admiralty. ${ }^{\circ}$ It is, then, only with regard to matters of competency of witnesses that the federal equity and admiralty courts are bound to follow the state law of evidence; as to other matters they are free to develop their own evidentiary principles. ${ }^{10}$

In this connection, it is noteworthy that, under the "Mode of Proof Act," providing that, "The mode of proof in causes of equity and of admiralty. and maritime jurisdiction shall be according to rules now or hereafter prescribed by the Supreme Court, except as herein specifically provided, ${ }^{\prime 11}$ the Court has done little or nothing toward prescribing rules of evidence either in equity or in admiralty. In both branches a general rule has been prescribed providing that the testimony of witnesses shall be taken orally in open court; and a few of the present Equity Rules touch on matters usually considered part of the law of evidence. ${ }^{12}$ But beyond this nothing has been done. It may be argued, and perhaps with good reason, that the Mode of Proof Act does not confer upon the Court power to make rules of evidence. ${ }^{13}$ A more likely reason for the

8. Russell v. Southard, 12 How. 139 (U. S. 1851) ; Mississippi Mills v. Cohn, 150 U. S. 202 (1893); Clark v. Andrew, 11 F. (2d) 958 (C. C. A. 5th, 1926); Miller v. Consolidated Royalty Oil Co., 23 F. (2d) 317 (C. C. A. 8th, 1927); Crum v. Patterson, 64 F. (2d) 263 (C. C. A. 3d, 1933); The William Jarvis, 29 Fed. Cas. No. 17,697, p. 1309; The Independence, 13 Fed. Cas. No. 7014, at p. 9.

9. 34 STAT. 618 (1906), 28 U. S. C. A. $\$ 631$ (1926).

10. Cf. 1 Wignore, Evidence (1923) \& 6.

11. U. S. Rev. Stat. $\S 862$ (1872), 28 U. S. C. A. $\S 637$ (1926). Formerly law cases also were included. 5 STar. 518 (1842) c. $188, \S 6$.

12. "In all trials in admiralty the testimony of witnesses shall be taken orally in open court, except as otherwise provided by statute, or agreement of parties, . . " Admirtilty Rule 46, 254 U. S. 698 (1920).

"In all trials in equity the testimony of witnesses shall be taken orally in open court, except as otherwise provided by statute or these rules. The court shall pass upon tho admissibility of all evidence offered as in actions at law. When evidence is offered and excluded, and the party against whom the ruling is made excepts thereto at the timc, tho court shall take and report so much thereof, or make such a statement respecting it, as will clearly show the character of the evidence, and the form in which it was offered, tho objection made, the ruling and the exception. If the appellate court shall be of the opinion that the evidence should have been admitted, it shall not reverse the decree unless it bo clearly of the opinion that material prejudice will result from an affirmance, in which event it shall direct such further steps as justice may require." Equity Rule 46, 226 U. S. 661 (1912). See also Equity Rules 47, ibid., and 64, id. at 668.

13. A distinction has been drawn between "Mode of Proof," or the manner of taking evidence, and a rule of evidence. This distinction was made in Bryant v. Leyland, 6 Fed. 
failure of the Supreme Court to prescribe extensive rules of evidence for equity and admiralty courts would seem to lie in the fact that it is only in common-law cases, where the jury is commonly used, that any such body of rules is needed. ${ }^{14}$ This distinction between jury and non-jury cases as a criterion of the usefulness of evidentiary restrictions, particularly rules of admissibility, should be a foremost consideration in determining the character of uniform federal rules of evidence in connection with the unification of law and equity under the new rules of civil procedure. $^{3}$

Because of their freedom not only from state rules, but, generally speaking, from any rules of evidence, the equity courts have had very little difficulty with questions of admissibility of testimony. Thus, for example, a search through the decisions of the various circuit courts of appeals, covering, roughly, the period of the last year, shows that not one of 573 equity cases coming from the district courts was reversed on a point of admissibility of evidence. In only a few were such points even considered. The same was true of the admiralty cases, though they were, of course, much fewer in number. On the other hand, $6.3 \%$ of $188 \mathrm{crim}$ inal cases were reversed on points of admissibility; and the situation was little better in cases at law, $4.5 \%$ being reversed out of a total of $682 .^{15}$ These latter percentages are not alarmingly high, but they indicate the difference between the importance of rules of admissibility in the jury as contrasted with the non-jury cases.

Quite a little danger to the freedom which the federal courts have en-

125, 127 (C. C. Mass. 1881), and in Chicago \& Northwestern Ry. Co. v. Kendall, 167 Fed. 62,65 (C. C. A. Sth, 1909). If applied in this situation, it would support the argument made. However, Equity Rule 64 would seem to be clearly within the rule of evidence class:

"All affidavits, depositions, and documents which have been previously made, read, or used in the court upon any proceeding in any cause or matter may be used before the master." 226 U. S. 668 (1912).

14. See 2 WigMtore, EvideAce (1923) § 8.

$\begin{array}{lccc}15 . & \text { Total } & \text { Involving admissibility of Evidence } & \begin{array}{c}\text { Reversed on } \\ \text { admissibility }\end{array} \\ \text { Equity } & 573 & 29 & 0 \\ \text { Law: Civil } & 682 & 126 & 31 \\ \text { Criminal } & 188 & 51 & 12 \\ \text { Admiralty } & 46 & 0 & 0 \\ & 1489 & 205 & 43\end{array}$

Of the cases at law, a large part of those in which a point of admissibility was involved were war risk insurance cases, turning usually on expert testimony. Biore often than not, these cases were reversed. This point was one of a very few matters of admissibility considered by the Supreme Court during the same period. See United States v. Spaulding, 293 U. S. 498 (1935), which was also a war risk insurance case.

As to the equity cases, it should be noted that Equity Rule 46 prohibits reversals on points of evidence unless material prejudice is shown. 
joyed as to rules of evidence in equity cases would seem to lurk in indiscriminate unification of evidence rules in both law and equity. Special provision for equity cases as well as for the increasing number of law cases tried without a jury would seem highly desirable.

\section{Criminal Cases}

In October 1933, the Supreme Court granted certiorari in two criminal cases in an effort to clear up a troublesome situation in the law of evidence applicable to such actions. In the first of these cases, Funk $v$. United States, ${ }^{16}$ the Court held that, in the absence of a controlling federal statute (and the Competency of Witnesses Act, being limited to civil controversies, would not so control), the competency of witnesses in criminal trials in the federal courts is to be governed by the common law; that the courts in interpreting the common law are not bound to follow such law as it existed at any specified time in the respective states but that they are free to interpret and apply it in the light of changed conditions and in line with the general current of legislative and judicial opinion. The second case in which certiorari was granted, Wolfle v. United States, ${ }^{17}$ held admissible the testimony of a stenographer as to a communication made by a husband to his wife through the medium of the witness, the stenographer testifying from notes. The court re-affirmed the principle of the Funk Case and made it clear that it applied not only to competency of witnesses but to admissibility of evidence as well. These two decisions free the federal courts in criminal cases from the last vestige of the static conformity doctrine of the earlier decisions-that the common law was to be determined as of the date of the entrance of the state into the union-and clears the way for a development of the law of evidence in criminal trials along modern lines. However, this method of development may prove troublesome because of the slow accretion of case law with its possible attendant uncertainty until new rules have been worked out by decisions. ${ }^{18}$

16. 290 U. S. 371,381 (1933). For a history of the criminal cases up to 1930, see Leach, State Law of Evidence in the Federal Courts (1930) 43 Harv. L. Rev. 554, 555-566, Sweeney, Federal or State Rules of Evidence in Federal Courts (1932) 27 Ir... L. REv. 394.

17. 291 U. S. 7 (1934).

18. See Comment (1934) 43 Yare L. J. 849, asserting that the principle of the Funk casc will result in too many appeals being taken and suggesting a statute making state rulcs applicable in order to avoid the laborious process of creating a separate body of federal evidence; Comment (1934) 47 Harv. L. REv. 853, suggesting a statute giving the Supreme Court porver to enact uniform rules of evidence in advance; and to same effect, Comment (1934) 28 ILL. L. REv. 846.

For favorable comments on the Funk and Wolfle cases see (1934) 22 CaITF. L. REv. 448; (1934) 22 Geo. L. J. 626; (1934) 19 Iowa L. REv. 488; (1934) 18 MnN. L. Rev. 893 (also suggesting rules of court); (1934) 9 Notre DAare LAwy. 373; (1934) 13 ORE, L. Rev. 259; (1934) 8 St. JohN's L. Rev. 375; (1934) 19 St. Lovis L. Rev. 157; (1934) 12 TEx. 


\section{Common-law Cases}

It is within the remaining general field, actions at law, that the greater part of the confusion exists. There is good authority to the effect that the Conformity Act is controlling in matters of evidence; ${ }^{10}$ but in general the courts have looked to the Rules of Decisions Act. ${ }^{20}$ So long as both acts are in force it can make very little difference which is regarded as controlling. Either furnishes the basis for the same divergence of opinion as to what is state law. ${ }^{21}$ Where there is an applicable state statute, the opinions seem to be unanimous that a federal court must follow such statute on matters of evidence. ${ }^{22}$ But where the state law is purely judicial and without statutory basis, as is the case with a large part of evidence, conflict ensues. Here a dispute of no small proportions has developed, engendered by the often attacked, but still firmly entrenched, doctrine of Sreift v. Tyson..$^{23}$ In general, the dispute has been one among circuits; but, as will be seen presently, the holdings within particular circuits are, in some instances, far from clear.

L. Rev. 473; (1934) 1 U. of Cer. L. Rev. 785; (1934) 20 VA. L. Rev. 590; (1934) 40 W. VA. L. Q. 270.

19. Keur v. Weiss, 37 F. (2d) 711 (C. C. A. 4th, 1930); De Soto Ifotor Co. v. Stewart, 62 F. (2d) 914 (C. C. A. 10th, 1932).

20. Nashua Savings Bank v. Anglo-American Co., 1S9 U. S. 221 (1903); Chicago \& Northwestern Ry. Co. v. Kendall, 167 Fed. 62 (C. C. A. 8th, 1909); Franklin Sugar Refining Co. v. Luray Supply Co., 6 F. (2d) 218 (C. C. A. 4th, 1925); Yon Crome v. Traveler's Ins. Co. of Hartford, Conn., 11 F. (2d) 350 (C. C. A. sth, 1926); Mracsachusstts Bonding \& Ins. Co. v. Norwich Pharmacal Co., 18 F. (2d) 934 (C. C. A. 2d, 1927).

21. See the Rules of Decisions and Conformity Acts, supra notes 6, 7.

22. Turner Simplicity Manufacturing Co. v. Bremner, 40 F. (2d) 36s (C. C. A. 8th, 1930) ; Pariso v. Towse, 45 F. (2d) 962 (C. C. A. 2d, 1930); Pure Oil Pipe Line Co. v. Ross, 51 F. (2d) 925 (C. C. A. 10th, 1931); Langsenkamp v. Brosealsa Chemical Co., 21 F. (2d) 207 (S. D. Ohio, 1927).

23. 16 Pet. 1 (U. S. 1842).

On the general proposition of Swift v. Tyson, see: Dobie, Seven Implications of Strijt v. Tyson (1930) 16 VA. L. Rev. 225; Green, The Law as Precedent, Prophecy, and Principle; State Decisions in Federal Couts (1924) 19 Irr. L. Rev, 217; Schofeld, Srrift v. Tyson: Uniformity of Judge-made Law in State and Federal Courts (1910) 4 InL. L. REv. 533; Shelton, Concurrent Jurisdiction-Its Necessity and its Dangers (1928) 15 VA. L. REv. 137; Shulman and Jaegerman, Sonze Jurrisdictional Limitations on Federal Procedture (1936) 45 YALE L. J. 393, 402, n. 36.

The Supreme Court recently set at rest any doubts which might have arienn regarding Swift v. Tyson as applied to the decisions of state courts construing state statutes. In Burns Mortgage Co. v. Fried, 292 U. S. 487 (1934), the Court held that such a judicial construction of a state statute was as binding on the federal courts as if "the state court's decision were literally incorporated into the enactment." Cf. Mrarine National Exchange Bank v. Kalt-Zimmers Mfg. Co., 293 U. S. 357 (1934); see Fordham, Surift v. Tyson and the Construction of State Statutes (1935) 41 W. VA. L. Q. 131; Comments (1935) $4 S$ Eusv. L. Rev. 132; (1935) 20 Iowa L. Rev. 155; (1935) 33 MIrcr. L. Rev. 434; (1935) U. OF PA. L. REv. 83. 
The Eighth Circuit has been the leader in holding that federal courts should not be dominated by non-statutory evidence rules of the states. In the case of Chicago \& Northwestern Ry. Co. v. Kendall, Judge Amidon, in an opinion which has become a classic, supported Swift v. Tyson in application to matters of evidence: $:^{24}$

"The basis of decision in these cases (Swift v. Tyson and Baltimore, Etc. Ry. Co. v. Baugh (1898), 149 U. S. 368) was this: That the general rules of commercial law and of the law of negligence had been the creation of the courts, and that the Federal Judiciary could not accept the law on such a subject from state courts without being placed in a position of direct subserviency to those courts. To maintain their own dignity and independence, it was therefore declared to be their duty to exercise an independent judgment on such subjects. The common law rules of evidence come clearly within the principle which was controlling in those decisions. ... They emanate from the minds of judges, and not from the practices of the business world. ... To compel the Federal Judiciary to accept rules on such a subject from the decisions of local courts is to place them in a position of direct tutelage to such courts, and to rob them of the dignity and independence of judgment which has heretofore been regarded as an indispensable part of their jurisdiction."

A similar position has been taken in the Second, ${ }^{25}$ Sixth, ${ }^{28}$ and Tenth $^{27}$ circuits.

In spite of the respect which other courts have extended to the opinion of Judge Amidon, ${ }^{28}$ three recent decisions of the Circuit Court of Appeals of the Eighth Circuit seem to desert his opinion. The first of these cases, Von Crome v. Traveler's Ins. Co. of Hartford, Conn. ${ }^{20}$ involved the admissibility of a certificate of the cause of the insured's death, which was issued by the state department of motor vehicles. The court held the certificate admissible on the following ground:

"It is well settled that under the so-called Conformity Act of Congress of September 24, 1789, c. 20, $\S 34$; Section 721, R.S., the competency of evidence in a civil case is determinable by the law of the state wherein the trial is had. Parker v. Moore (C. C.) 111 F. 470; Wright v. Bales, 2 Black, 535, 17 L. Ed. 264. So much being settled, the case of Griffith

24. 167 Fed. $62,67-68$ (C. C. A. 8th, 1909).

25. Massachusetts Bonding \& Ins. Co. v. Norwich Pharmacal Co., 18 F. (2d) 934 (C. C. A. 2d, 1927) (Here Judge Hand chose to follow Judge Amidon's opinion in the Kendall case, characterising it as "careful and satisiactory."); Pariso v. Towse, 45 F. (2d) 962 (C. C. A. 2d, 1930).

26. Garrett v. Southern Ry. Co., 101 Fed. 102 (C. C. A. 6th, 1900); Louisville \& Nashville Rr. Co. v. McClish, 115 Fed. 268 (C. C. A. 6th, 1902); West Tennessec Grain Co. v. J. C. Shaffer \& Co., 299 Fed. 197 (C. C. A. 6th, 1924). A more recent case is Lawson v. Twin City Fire Ins. Co., 2 F. Supp. 171 (E. D. Ky. 1932), a case involving the parol evidence rule.

27. De Soto Motor Corp. v. Stewart, 62 F. (2d) 914 (C. C. A. 10th, 1932).

28. Pariso v. Towse; Massachusetts Bonding \& Ins. Co. v. Norwich Pharmacal Co, both supra, note 25; Rison v. Postal Telegraph-Cable Co., 28 F. (2d) 788 (N. D. Cal. 1928 ). 
v. Continental Casualty Co., 253 S. W. 1043, 299 Mo. 426, wherein the identical point was ruled, settles the point against plaintifi's contention." $2=0$

The Eighth Circuit cases to the contrary were not mentioned. This decision was followed in Chicago Fire \& Mlarine Ins. Co. v. Hyde Park Congregational Church, ${ }^{30}$ and in Aetna Life Ins. Co. v. Kelley, ${ }^{31}$ both of which arose in Missouri and decided the points of evidence solely from the Missouri decisions, without so much as mentioning the rule of the Kendall Case. Although not in accord with the earlier opinions of the Eighth Circuit, these cases do follow the rule which has been adopted by the courts of the First, Fourth, Fifth, Seventh, and Ninth Circuits, which have held that the federal courts are controlled by the law of evidence contained not only in the statutes but also in the court decisions of the state in which they are sitting..$^{32}$

The Supreme Court has used language which would seem to indicate a leaning toward the conformity side of the dispute. One case, Nashula Savings Bank v. Anglo-American Co., ${ }^{33}$ frequently is cited as so holding. But the proponents of uniformity have disputed that point and have argued with considerable force that the question has not been foreclosed by any Supreme Court decision. ${ }^{34}$ This position seems justified by the relatively recent decision in Leach. \& Company, Inc. v. Peirson, ${ }^{35}$ in which it was contended that the defendant's failure to reply to a letter asserting a contract with the defendant's agent constituted an admission of the agent's authority to make the contract. Certiorari was granted by the Supreme Court, "On a suggestion of conflict between this (the Third Circuit) and other Circuit Courts of Appeal and of failure to conform to the rule of evidence in Pennsylvania, ... as also of a difference among the

29. 11 F. (2d) 350,352 (C. C. A. Sth, 1926). The statute cited in the quotation is the one we have referred to as the "Rules of Decisions Act."

30. 35 F. (2d) 73 (C. C. A. 8th, 1929).

31. 70 F. (2d) 589 (C. C. A. Sth, 1934).

32. Stewart v. Miorris, 88 Fed. 461 (C. C. A. 7th, 1898); American Agricultural Chemical Co. v. Hogan, 213 Fed. 416 (C. C. A. 1st, 1914); Myers v. Moore-Kile Co., 279 Fed. 233 (C. C. A. 5th, 1922); Standard Oil Co. v. Cates, 28 F. (2d) 71S (C. C. A. 4th, 1928); Metropolitan Casualty Ins. Co. v. Smith, 58 F. (2d) 699 (C. C. A. 9th, 1932); Alezander v. Missouri State Life Ins. Co., 68 F. (2d) 1 (C. C. A. 7th, 1933).

33. 189 U. S. 221 (1903).

34. Chicago \& Northruestern Ry. Co. v. Kendall, 167 Fed. 62, 67 (C. C. A. 8th, 1909). In the Nashuca case, involving the proof of English statutes through a deposition of an English solicitor, the statement was made: "The laws of the several states with respect to evidence within the meaning of this section apply not only to statutes, but to the decisions of their highest courts." Judge Amidon says the statement above was not necessary to the decision of the case. It should be noted, however, that the Court cited a New Hampshire case (the Nashua case arose in that state) along with some others, to the effect that the statute could be proved in that manner. But there is no reason to believe that the New Hampshire case played a greater part in the decision than those from other jurisdictions.

35. 16 F. (2d) 86 (C. C. A. 3d, 1926), cert. allowed, 273 U. S. 676 (1926). 
courts as to the scope of the Conformity Acts." ${ }^{236}$ But the court did not treat the general problem; it held merely that the contention of the plaintiff was unsound, citing two cases from Pennsylvania (in which state the case arose), four federal cases (from the Second, Fourth, Sixth and Eighth circuits), a Massachusetts, a New York and three English cases. The conclusion would thus seem to be that the Pennsylvania cases were not controlling in and of themselves, but rather that the question of evidence was to be answered more on the general authority principle now applied in criminal cases.

A new and interesting angle was added to the whole question by a recent decision of the Circuit Court of Appeals for the Fifth Circuit, which previously had held for conformity. ${ }^{32}$ In Royal Ins. Company, Ltd. v. Eastham, ${ }^{37}$ the trial court had refused to allow a party to question his own witness with a view to impeaching him. It was asserted on appeal that the law of the state (Alabama) allowed such a procedure. The court said:

"There is a conflict of opinion as to whether, in evidentiary matters of this kind, federal courts will follow the decisions of the state of the trial. We think that there is no hard and fast rule that they must, or they must not. We think it was within the sound discretion of the judge here to determine which rule he would follow, and that no abuse of that discretion was shown."

Although this division of opinion exists when the courts are confronted squarely with the question of whether or not they must follow a state decision on a particular point, it is submitted that such considerations have not played much part in deciding the general run of evidence cases in the federal courts. The typical approach has been similar to that of the Supreme Court in the Peirson Case, ${ }^{36}$ that is, to regard matters of evidence as questions to be settled by general authority rather than by reference to the law of the particular state. Connecticut Mutual Life Ins. Co. v. Lathrop, ${ }^{38}$ was an action on an insurance policy to which the defense of suicide was offered. Non-professional, non-expert witnesses were allowed to state to the jury their opinions as to the state of the insured's mind shortly before his death. The Supreme Court sustained the admission of the testimony on the basis of reason and authority, and cited, in addition to its own decisions, cases from England, Connecticut, Vermont, New Hampshire, Illinois, Pennsylvania, Ohio, Iowa, California, Texas and one from Missouri, the state in which the case arose. The opinion made no reference to the Missouri law, as such, and it is obvious that the Missouri case was given only incidental consideration. ${ }^{30}$

36. Holmes, J., in Leach \& Co. v. Peirson, 275 U. S. 120, 127 (1927).

37. 71 F. (2d) 385 (C. C. A. 5th, 1934).

38. 111 U. S. 612 (1884).

39. See also New Jersey Steamboat Co. v. Brockett, 121 U. S. 637 (1887) ; Bates v. Preble, 


\section{Competency of Witnesses}

- The Conformity Act and the Rules of Decisions Act do not expressly refer to evidence but have been construed to cover the subject, as heretofore pointed out. On the other hand, the question of competency of witnesses in civil cases is expressly regulated by federal statute, directing conformity to state law." What is meant by "the laws of the state"? Certainly statutes are included; and the court, in construing such statutes, is to be guided by the construction placed upon them by the highest courts of the state. ${ }^{41}$ The question as to whether the act requires federal courts to follow state rules as to competency of witnesses created by judicial decision, is largely academic since the trend toward the removal of common-law disqualifications of witnesses has been entirely statutory. ${ }^{2}$

In the past the operation of the statute has been somewhat clouded by . skirmishes over the meaning of the phrase "Competency of Witnesses". The Supreme Court, in Connecticut MIutual Life Ins. Co. v. Schacfer,"3 intimated that the attorney-client privilege was within the purview of the statute. Obviously, such an interpretation fails to make the technical distinction between competency and privilege. ${ }^{4}$ As a matter of fact, the statute as it then existed, with a provision regarding testimony as to transactions with deceased persons, was not limited to competency of witnesses in the technical sense, since a witness was not made incompetent to take the stand but was prohibited from testifying only as to certain matters. ${ }^{45}$ Such testimony is, however, still regarded as being controlled by the Competency of Witnesses Act, even since the special

151 U. S. 149 (1894); Leonard v. St. Joseph Lead Co., 75 F. (2d) 390 (C. C. A. 8th, 1935); Halleck v. Hartford Accident \& Indemnity Co., 75 F. (2d) 800 (C. C. A. 5th, 1935); Hawthorne v. Eckerson Co., 77 F. (2d) 844 (C. C. A. 2d, 1935) ; Arkansas Natural Gas Co. v. Sartor, 78 F. (2d) 924 (C. C. A. 5th, 1935). Botes $\%$. Preble and the Hallects cace cite cases from the states in which they were tried; but such cases are considered only along with others. The Brockett case was tried in New York, but no case from that state was cited although the point had been passed upon repentedly. Luby v. Hudson River Rr. Co., 17 N. Y. 131 (1858); Anderson v. Rome W. \& O. Rr. Co., 54 N. Y. 334 (1873).

40. See "Competency of Witnesses Act" set out supra.

41. McBride v. Kirkpatrick, 207 Fed. 893 (D. W. Va. 1913), afinrmed, 232 Fed. 859 (C. C. A. 4th, 1916) ; Central Iron \& Coal Co. v. Hamacher, 248 Fed. 50 (C. C. A. 5th, 1918).

42. Leach, supra note 16.

43. 94 U. S. 457,458 (1876).

44. See Downs v. Wall, 176 Fed. 657 (C. C. A. 5th, 1910), holding that the section has no application to admissibility of evidence.

45. "That Chapter 210, sec. 3 be amended by adding thereto the following proviso: Provided, further that in actions by or against esecutors, administrators, or guardians, in which judgment may be rendered for or against them, neither party shall be allowed to testify against the other as to any transaction with or statement by the testator, intestate, or ward, unless called to testify by the opposite party, or required to testify thereto by: the court." 13 STat. 533 (1865). 
provision was jettisoned in $1906 .^{48}$ The Court's classification of the attorney-client privilege as within the Act has caused considerable diffculty, as will be seen.

As applied to questions of competency the principle of conformity seems, in general, to have worked well. Conformity, being prescribed by federal statute, and the state law of competency being generally of a statutory nature, questions of competency of witnesses in civil cases have seldom arisen in recent years to vex federal appellate courts. To this, however, there is one notable exception.

When, in 1906, the federal statute was amended to omit the express disqualification of a party to testify as to transactions with a deceased or incompetent person in an action by or against the representatives of such person, the effect merely was to substitute state statutes having, in general, the same provisions. This disqualification has been regarded as the most unsatisfactory rule in all the law of competency; ${ }^{47}$ and certainly it is the most productive of legal and practical difficulties. The various state statutes have been before state ${ }^{48}$ and federal ${ }^{40}$ courts of appeal innumerable times. The case against the rule has been summed up as follows: "This restriction not infrequently works intolerable hardship in preventing the establishment of a meritorious claim. Furthermore, it has been enforced with the most rigorous literalness, and has been the occasion of a labyrinth of subtle decisions. A long experience leads me to believe that the evils guarded against do not justify the retention of the rule." ${ }^{20}$

\section{Privileged Communications}

Privileged communications, controlled as they usually are by state statutes, should have presented little trouble in law actions. It is now generally true that in this field the federal courts are governed by such state statutes; but it is not entirely clear under which of the acts of Congress the courts are so governed. ${ }^{51}$ It would seem that the matter

46. Rankin v. Cox, 71 F. (2d) 56 (C. C. A. 8 th, 1934).

47. See Morgan and otzers, The Law of Evidence (1927) 23 et seq.

48. Id. at 27.

49. Some of the more recent federal cases construing state statutes are: Maryland Casualty Co. v. Cook-O'Brien Const. Co., 69 F. (2d) 462 (C. C. A. 8th, 1934); Brelsford v. Whitney Trust \& Savings Bank, 69 F. (2d) 491 (C. C. A. 5th, 1934); Rankin v. Cox, 71 F. (2d) 56 (C. C. A. 8th, 1934); Northern Trust Co. v. Elman, 72 F. (2d) 169 (C. C. A. 6th, 1934).

50. Henry W. Taft, Comments on Will Contests in New York (1921) 30 YaLE L. J. 593, 605.

51. Connecticut Mutual Life Insurance Co. v. Union Trust Co., 112 U. S. 250 (1884); Witters v. Sowles, 32 Fed. 130 (C. C. Vt. 1887) ; Mutual Benefit Life Ins. Co. v. Robinson, 58 Fed. 723 (C. C. A. 8th, 1893); American Ry. Express Co. v. Rowe, 14 F. (2d) 269 (C. C. A. 1st, 1926); Lloyd v. Pennie, 50 Fed. 4 (D. Cal. 1892). The Union Trust Co. case and the Rowe case based their decisions on the Rules of Decisions Act; the others on the Competency of Witnesses Act. 
is not one of competency of witnesses and should not be governed by the federal statute on that subject. ${ }^{44}$ But an early and unfortunate decision by the Supreme Court has confused the situation considerably. In Connecticut Mutual Life Insurance Co. v. Schaeffer, questioned as to a statement made to him by his client, the plaintiff in the instant case. An objection to the question was sustained on the ground of privileged communication. It was alleged that this was error because by the law of Ohio, where the case arose, such communications were not privileged. The Court expressed doubt as to the Ohio law but held the testimony rightly excluded regardless of such law, statutory or otherwise. The basis upon which this conclusion was reached is vague, but it seems to have been that state laws can control matters of evidence in federal courts only insofar as Congress has not legislated on the subject, that Congress had covered this situation in the Competency of Witnesses Act and that such act made no provision for the admission in evidence of previous communications to counsel. ${ }^{53}$ This construction of the statute is inexplicable and was abandoned eight years later in Connecticut Mrutual Life Ins. Co. v. Union Trust Co., without mention of the Schaeffer case. ${ }^{\text {st }}$ Here, too, the Supreme Court held the testimony rightly excluded, but this time it was because of the state statute, which the federal courts were required to follow under the Rules of Decisions Act. Nothing was said as to the Competency of Witnesses Act except that it did not modify the Rules of Decisions Act as applied to the instant case. Thus the Schaeffer case was quietly buried; but its ghost continued to haunt the lower federal courts. The Circuit Court of Vermont later held that the Competency of Witnesses Act required conformity to a state statute on privilege, citing the Union Trust Co. case. ${ }^{\text {ES }}$ A district court in California applied the same federal statute to a question of privilege in an equity

52. 94 U. S. 457 (1876).

53. The Court said:

"An examination of the Ohio statutes renders it doubtful whether the law is as the defendant contends. But if it were, the court did right to exclude the teclimony. The laws of the State are only to be regarded as rules of decision in the Courts of the United States where the Constitution, treaties, or statutes of the United States have not otherrize provided. When the latter speak, they are controlling; that is to say, on all subjects on which it is competent for them to speak. There can be no doubt that it is compstent for Congress to declare rules of evidence which shall prevail in the courts of the United States, not affecting rights of property; and where Congress has declared the rule, the State las is silent. Now, the competency of parties as witnesses in the Federal courts depends on the act of Congress in that behalf, passed in 1864, amended in 1865, and codified in the Revised Statutes, sect. 858. It is not derived from the statute of Ohio, and is not subject to the conditions and qualifications imposed thereby. The only conditions and qualifiestions which Congress deemed necessary are expressed in the act of Congress; and the admission in evidence of previous communications to counsel is not one of them. And it is to be hoped that it will not soon be made such." 94 U. S. 457, 458 (1876).

54. 112 U. S. 250 (1884).

55. Witters v. Sowles, 32 Fed. 130 (C. C. Vt. 1887). 
case. $^{56}$ Regardless of the confusion in the reasons given, it will be noted that, on one ground or another, all of the above cases reached the same result, to wit, that the communications were privileged.

\section{Examination and Credibility}

One instance in which the courts have applied a uniform federal rule, controlling despite a state statute or decision to the contrary, is that regarding the scope of cross-examination. In Hendrey $v$. United States, ${ }^{\text {br }}$ an objection was sustained to a question on cross-examination on the ground that it called for an opinion. The reviewing Court held that the opinion was properly receivable but that the objection might have been sustained on the ground that the question was not germane to the examination-in-chief. The court said:

"We are told that according to the Tennessee practice, a witness may be cross examined on any matter material in the case; but state rules on this subject are not accepted by the federal courts, which are controlled by their own practice in this respect, and which do not permit cross-examination to go beyond the scope of the direct examination."

Some question has been raised as to the basis upon which this freedom from state rules has been established. One writer, while recognizing that the federal rule as to cross-examination is definitely established, feels, nevertheless, that such matters clearly should come under the Conformity Act. ${ }^{58}$ In the leading case, Wills $v$. Russell, ${ }^{50}$ the Court felt compelled by the fact that the same point had been "twice so ruled" in Philadelphia and Trenton Railroad Co. v. Stimpson, ${ }^{60}$ and Houghton v. Jones, ${ }^{01}$ neither of which attempt any justification of the rule. The answer now given seems to be that this question is not a general question of evidence nor a question of practice but that it is a part of the personal conduct and administration of the trial on the part of the judge; and in such matters the federal courts are not bound by state law, either statutory or judgemade. Such was the rationale of American Issue Publishing Co. v. Sloan, where the court refused to apply an Ohio statute permitting a party to call his adversary and examine him as upon cross-examination. ${ }^{02}$ What-

56. Lloyd v. Pennie, 50 Fed. 4 (N. D. Cal. 1892).

57. 233 Fed. 5 (C. C. A. 6th, 1916).

58. Williams, Federal Practice (2d ed. 1927) 313.

59. 100 U. S. 621 (1879).

60. 14 Pet. 448 (U. S. 1840).

61. 1 Wall. 702 (U. S. 1863).

62. 248 Fed. 251,253 (C. C. A. 6th, 1917). The reasoning in the Sloan case would seem to be a direct descendant of Wayman v. Southard, 10 Wheat. 1 (U. S. 1825), in which Chief Justice Marshall dove into a mass of statutory construction and came up with the proposition that the Rules of Decisions Act was "a mere legislative recognition of the principles of universal jurisprudence" and did not apply to the "process and practice of the courts." Under that decision, by calling the scope of cross-examination a matter of "practice," the application of state rules could be avoided. But in 1872 Congress passcd 
ever the reason for the rule, it is well settled that, in the absence of permission from the court, a party has no right to cross-examine as to any facts or circumstances not brought out in direct examination. This rule is applied alike in civil and criminal cases, and in all circuits. ${ }^{.3}$

There would seem to be no good reason why a distinction should be made between the scope of cross-examination and such matter as the necessity for laying a foundation to impeach a witness. If the former is part of trial administration, then the latter also should be so regarded, and an independent judgment exercised as to it. This was the view of the Supreme Court in Conrad v. Griffey. ${ }^{04}$ Here it applied the rule, now followed by the greater number of state courts, ${ }^{05}$ that in order to impeach a witness by evidence of prior contradictory statements, a foundation for such impeachment must be laid by first interrogating the witness as to such statements. But when confronted by a state practice to the contrary, the First Circuit reached the opposite result and distinguished the Conrad case on the ground that it "did not involve the existence of a well established state practice to the contrary." Thus the matter of impeachment was classed with the general rules of evidence.

\section{Burden of Proof and Presumptions}

Usually considered as a part of the law of evidence, the subject of burden of proof has, nevertheless, a strong substantive aspect. By reason thereof it has received, to some extent, a different treatment from the federal courts and, under the accommodating doctrine of Swift v. Tyson, uniform rules as to burden of proof have grown up in the federal courts in a few important instances. Of course, in order to come within Swift v. Tyson, it is not sufficient merely to say that burden of proof really is substantive. It must also present a question of "general law." If such a question exists, the federal court is not bound by state decisions, and may, in the absence of a controlling state statute, exercise an inde-

the Conformity Act which required observance of state "practice" in actions at common law. Silpra, note 7. Thus a further refinement became necessary; and we naw find a great number of subjects to which principles of conformity do not apply, not beause they are "general law," "evidence" or "practice," but because they are matters of "adminictration."

63. Wills v. Russell, 100 U. S. 621 (1879); Northern Pacific Rr. Co. v. Urlin, 158 U. S. 271 (1895); McKnight v. United States, 122 Fed. 926 (C. C. A. 6th, 1903); Hales v. Michigan Central Rr. Co., 200 Fed. 533 (C. C. A. 6th, 1912); Hendrey v. United States, 233 Fed. 5 (C. C. A. 6th, 1916); Farley v. Norfolk \& Western Ry. Co., 14 F. (2d) 93 (C. C. A. 4th, 1926); De Soto Motor Corp. v. Stewart, 62 F. (2d) 914 (C. C. A. 10th, 1932); Union Electric Light \& Power Co. v. Snyder Estate Co., 65 F. (2d) 297 (C. C. A. Sth, 1933); Fidelity \& Deposit Co. of Maryland v. Bates, 76 F. (2d) 160 (C. C. A. Sth, 1935). This rule, of course, does not apply where the matter in question is elicited to show bias or prejudice or to lay a foundation for impeachment. See IVills v. Russell, stipra.

64. 16 How. 38 (U. S. 1853).

65. 2 Wigitore, Evidence (2d ed. 1923) $§ 1028$. 
pendent judgment. To the extent, therefore, that burden of proof is a matter of general law it is freed from the operation of the conformity acts.

One important instance in which the federal courts have developed a uniform rule with respect to burden of proof is on the issue of contributory negligence. In the absence of a local statute regulating the matter, questions of contributory negligence are considered matters of general law, as to which the federal courts are not bound by state decisions. And it is definitely established in the federal courts that contributory negligence is an affirmative defense which the defendant must prove by a preponderance of the evidence, any difference in the common law of the state notwithstanding. ${ }^{6}$ The doctrine of general jurisprudence was first announced in a case involving commercial paper ${ }^{67}$ and, in the absence of statute, it has been applied to questions of burden of proof relating to such cases. Thus it has been held that where commercial paper, fair on its face, is in the hands of an innocent purchaser for value before maturity, the burden of proof is on the person claiming an alteration to have been made, irrespective of the decisions of the particular state, since it is a matter of general law. ${ }^{68}$ And it is a settled rule in the federal courts that the burden of proving bad faith on the part of a person who took negotiable paper before maturity and for value is on the party asserting such bad faith. ${ }^{69}$

A further instance in which the question of burden of proof may be decided by the federal courts without regard to the law of the state occurs where a federal statute is involved. In Hill v. Smith ${ }^{70}$ it was held that a creditor who wished to escape the effects of a discharge in bankruptcy must prove himself within the exception of the statute. The creditor, on the other hand, contended that questions of burden of proof are to be determined by state practice, irrespective of the fact that the issues in dispute may be raised under a federal statute. But the court held the

66. Railroad Co. v. Gladmon, 15 Wall. 401 (U. S. 1872); Indianapolis and St. Louis Rr. Co. v. Horst, 93 U. S. 291 (1876); Hough v. Railway Co., 100 U. S. 213 (1879); Washington \& Georgetown Rr. Co. v. Harmon, 147 U. S. 571 (1893); Central Vermont Ry. Co. v. White, 238 U. S. 507 (1915); Hemingway v. Illinois Central Rr. Co., 114 Fed. 843 (C. C. A. 5th, 1902).

67. Swift v. Tyson, 16 Pet. 1 (U. S. 1842).

68. First National Bank of Shenandoah v. Liewer, 187 Fed. 16 (C. C. A. 8th, 1911).

69. Doe v. Northwestern Coal \& Transportation Co., 78 Fed. 62 (C. C. Ore. 1896); First National Bank v. Moore, 148 Fed. 953 (C. C. A. 9th, 1906); Young v. Lowry, 192 Fed. 825 (C. C. A. 3d, 1912).

It is not error for a federal court to follow a rule as to burden of proof announced by the courts of the state in which it is sitting, when no rule of general commercial law of which the federal courts will take cognizance has been pressed in the trial court. North Philadelphia Trust Co. v. Smith, 13 F. (2d) 585 (C. C. A. 3d, 1926).

70. 260 U. S. 592 (1922). 
burden of proof to be so connected with the substantive rights given by the statute as to make it a federal question.

Closely related to this subject is the matter of presumptions, the number of which, both statutory and otherwise, is legion. This problem has been drawn into the same inter-circuit struggle which characterizes the general law of evidence in the federal courts. ${ }^{71}$ But, as in the case of rules of admissibility, the courts, in the general run of cases, have decided questions of presumptions from general authority without particular reference to the law of the instant state. ${ }^{72}$ Unhampered by the conformity problem, the technique of two recent federal cases in dealing with the presumption of the possibility of issue is worthy of note. In United States v. Provident Trust $\mathrm{Co}^{73}$ the question involved the value, for purposes of the Federal Estate Tax, of a devise to charities of a remainder contingent upon the death without issue of a female life tenant. The Government contended that no deduction for the charitable devise could be made because of the conclusive presumption that a woman is capable of bearing children so long as she lives. But the Court refused to follow the presumption in view of unquestioned testimony that a surgical operation, which had been performed on the woman in question, has made the birth of issue impossible. The reasoning is strikingly similar to that which the federal courts have employed in deciding questions of evidence in criminal cases. ${ }^{74}$ The Court was careful to confine itself to the case at hand, pointing out that it did not involve the rule against perpetuities or any other situation such as constituted the background of the presumption. And it was emphasized that the question arose with respect to a surgical operation and not impossibility resulting merely from age. But, almost simultaneously with this decision, the District Court for the Southern District of New York refused to follow the presumption solely because of the age of the woman involved. ${ }^{75}$ As to whether the

71. Pariso v. Towse, 45 F. (2d) 962 (C. C. A. 2d, 1930). This case dealt with a statute of the state of New York providing that possession of a motor car raised a presumption that the owner consented to its use. Judge Hand said: "In the case at bar it makes a critical difference that these questions do not arise in an action at common law, in which event the District Court would not be bound by the rules of evidence as understood by the state court-at least not in this circuit." But the court conceded that it must follow the state statute raising the presumption and held that the procedure adopted by the state courts in its administration was as authoritative and binding upon the federal courts sitting within the state as the tert of the act.

72. See Atchison, T. \& S. F. Co. v. De Sedillo, 219 Fed. 686, 689 (C. C. A. Sth, 1915); Miller v. Union Pac. Rì. Co., 63 F. (2d) 574 (C. C. A. Sth, 1933); Mietropolitan Life Ins. Co. v. Hogan, 63 F. (2d) 654 (C. C. A. 7th, 1933) ; Equitable Life Assur. Soc. v. Halliburton, 67 F. (2d) 854 (C. C. A. 10th, 1933).

73. 219 U. S. 272 (1934).

74. See Comment (1934) 43 YaLE L. J. 1193.

75. City Bank Farmers' Trust Co. v. United States, 5 F. Supp. 871 (1934). The court took judicial notice of statistics published by the Department of Commerce showing 
rule of the Provident Trust Company case will be extended to affect the presumption in other than tax cases, it is too early to predict. That such an extension would be desirable is scarcely open to serious doubt. But in cases involving matters other than federal taxation, decisions of state courts holding the presumption irrebuttable may present a serious obstacle to such an extension in those circuits which choose to follow state rules of evidence.

\section{Specific Federal Statutes on Evidence}

The federal statutes discussed above intended to procure conformity to state law, have, as we have seen, been general in character. Failing in their objective of conformity to state law they have created much uncertainty. Now we turn to federal statutes, specific in character, whose objective is uniformity.

One group of such statutes dealing with the mode of proof in the trial of common-law actions is extremely important. The general provision is that such proof "shall be by oral testimony and examination of witnesses in open court, except as hereinafter provided."78 The exceptions are numerous, dealing at length with depositions, when and how they may be taken and used. ${ }^{77}$ The general objective is thoroughly desirable. ${ }^{78}$ But the exclusionary language has thwarted the adoption of state methods, which might otherwise have been made applicable in the federal courts by the Conformity Act. Thus, where the object was to obtain testimony for trial purposes, a federal court sitting in New York was precluded from adopting the state practice whereby the adverse party to an action could

that out of $2,169,920$ births in the United States during 1929, not one was to a mother of fifty-five or over. This decision was affirmed by Judge Hand, in 74 F. (2d) 692 (1935), who could find no essential difference between the surgical operation and the advanced ago of the woman as reasons for discarding the presumption, since in each case the conclusion that no issue was possible rested on the accuracy of the data and correctness of scientific conclusions. Another tax case, arising earlier in the First Circuit, applied the presumption. Farrington v. Commissioner of Internal Revenue, 30 F. (2d) 915 (C. C. A. 1st, 1929).

76. U. S. Rev. Stat. § 861 (1878), 28 U. S. C. A. $\$ 635$ (1926). The corresponding provision for equity and admiralty reads: "The mode of proof in causes of equity and of admiralty and maritime jurisdiction shall be according to rules now or hereafter prescribed by the Supreme Court, except as herein specially provided." U. S. REv. STar. $\$ 862$ (1878), 28 U. S. C. A. $\S 637$ (1926).

77. These are conveniently grouped in 28 U. S. C. A. $\$ \S 639-648$ (1926).

78. This is now the practice in equity under Rule 46 which abolished the older practice of written proof, and adopted the English practice of oral testimony in open court save where special cause exists for taking testimony otherwise. It represents almost a complete return to the practice prescribed in the first Judiciary Act, 1 Srar. 83 (1789). Rulo 47, providing for the taking of depositions in exceptional instances, is supplementary to Rule 46 , and does not vary or limit the statutory provisions relative to taking depositions. Rulc 48, supplementary to the foregoing two rules, provides that the district court may, upon petition, order the testimony in chief of expert witnesses, in patent and trademark causes, to be set forth in affidavit within a certain prescribed time after the issues are made up. See Hopkins, FEDERAL EQuITY Rules (8th ed. 1933) 249-257. 
be compelled to submit to examination. ${ }^{79}$ Mr. Justice Miller, in construing the above-mentioned provisions, said:

"No one can examine these provisions for procuring testimony to be used in the courts of the United States, and have any reasonable doubt that, so far as they apply, they were intended to provide a system to govern the practice, in that respect, in those courts. They are, in the first place, too complete, too far-reaching, and too minute to admit of any other conclusion. But we have not only this inference from the character of the legislation, but it is enforced by the express language of the law in providing a defined mode of proof in those courts, and in specifying the only exceptions to that mode which shall be admitted." 80

Although the federal courts have no common-law power to compel a plaintiff in a personal injury action to submit to a surgical examination prior to trial, ${ }^{\text {st }}$ yet, where a litigant voluntarily submits the injured part to the jury for inspection, the court has the power and duty to require the litigant to submit to a physical examination by surgeons. ${ }^{82}$ And where there is an applicable state statute, a plaintiff, in this type of action, may be compelled to submit to a physical examination during trial. This result, it is said, does not conflict with the federal legislation under discussion, because the evidence thus acquired must be presented to the court in the manner dictated by that legislation. ${ }^{83}$ And a state statute has been followed whereby a party could examine his adversary for the purpose of framing his pleading, since, as Judge Learned Hand put it, "An examination to frame a pleading is quite another thing from a perpetuation of testimony to be used in proof of the issues."134 On the same theory, where there is an applicable state statute, premises and physical objects have been examined before trial for the purposes of framing a pleading; $;^{85}$ and also to secure evidence, subsequently submitted to the court pursuant to the requirements of the federal legislation under discussion. ${ }^{86}$ But because of an ancient federal statute providing that "in the trial," construed to mean "at the trial," of actions at law a party may be compelled to produce books and documents, a state

79. Ex parte Fisk, 113 U. S. 713 (1885).

80. Id. at 722-723. Quoted with approval in Hanks Dental Ass'n v. International Tooth Crown Co., 194 U. S. 303, 306 (1904), which held that the Act of 1S92, 27 Srar. 7, 28 U. S. C. A. $\$ 643$ (1926), providing an additional mode of taking depositions, namely, in accordance with the state laws, did not alter the law of Ex farte Fish, but only added another mode of taking depositions.

81. Union Pacific Ry. Co. v. Botsford, 141 U. S. 250 (1891).

82. Chicago, etc. Ry. Co. v. Kendall, 167 Fed. 62 (C. C. A. sth, 1909).

83. Camden \& Suburban Ry. Co. v. Stetson, 177 U. S. 172 (1900).

84. Donnelly v. Anderson Brown \& Co., 275 Fed. 438,439 (S. D. N. Y. 1921).

85. Wilson v. New England Navigation Co., 197 Fed. Ss (E. D. N. Y. 1912) (goad discussion of the federal situation).

86. Mills v. Providence Belting Co., 145 Fed. 447 (C. C. D. R. I. 1906); Gimenes : N. Y. \& Porto Rico S. S. Co., 37 F. (2d) 168 (S. D. N. Y. 1929). 
practice whereby the production of books and documents may be required prior to trial is not available. ${ }^{87}$ There is, therefore, at present no method of discovering books or papers before trial on the law side of the federal courts; ${ }^{88}$ but a bill of discovery is available in equity. ${ }^{80}$

Another group of statutes, dealing with the proof of public documents and records, is fragmentary in character and not wholly satisfactory. There is nothing covering foreign judicial or public records (excepting foreign letters patent), ${ }^{90}$ or federal judicial records (other than in bankruptcy). ${ }^{91}$ There is no general provision governing the proof of records of United States offices, although there are quite a few statutes on proof of federal departmental records. ${ }^{02}$ Some of the statutes deal with methods

87. Carpenter v. Winn, 221 U. S. 533 (1911), construing U. S. REv. STAT. $\$ 724$ (1878), 28 U. S. C. A. $\S 636(1926)$.

88. Ibid.; Kaiser v. Chicago, St. P., M. \& O. Ry. Co., 192 Fed. 1013 (D. Minn. 1912); Chatz v. Winton Motor Carriage Co., 197 Fed. 777 (S. D. N. Y. 1911).

89. General Film Co. v. Sampliner, 232 Fed. 95 (C. C. A. 6th, 1916). And see Carpenter v. Winn, 221 U. S. 533, 539 (1911), where Mr. Justice Lurton said that the equitable procedure for discovery "is still open if it is desired to have the evidence produced beforo the trial. A court of equity does not lose its jurisdiction to entertain a bill for the discovery of evidence or to enjoin the trial at law until obtained, because the powers of the courts of law have been enlarged so as to make the equitable remedy unnecessary in some circumstances." In the last sentence he was referring to U. S. REv. STAT. \$724 (1878), 28 U. S. C. A. $\$ 636$ (1926). The statement may have been unnecessary to the decision of the case, but it was accepted as authoritative by the Circuit Court of Appeals in General Film Co. v. Sampliner, and has been so accepted by other courts. Sce the citations in the General Film Co. case, at 98.

90. U. S. Rev. Stat. § 893 (1878), 28 U. S. C. A. $\$ 674$ (1926).

91. 30 Stat. 551 (1898), as amended in 32 STAT. 798 (1903), 11 U. S. C. A. $\$ 44$ (1926).

92. U. S. Rev. Stat. \$ 882 (1878), as amended 48 StAT. 1109 (1934), 28 U. S. C. A. $\$ 661$ (Supp. 1935), admissibility of copies of records and papers: of executivo departments and corporations wholly owned by the United States. U. S. REv. STAT. \& 883 (1878), 28 U. S. C. A. $\S 662$ (1926), same: Solicitor of Treasury. U. S. REv. STAT. $\S 884$ (1878), 28 U. S. C. A. $\$ 663$ (1926), same: Comptroller of Currency. U. S. Rev. STaT. $\$ 885$, 28 U. S. C. A. $\$ 664$ (1926), admissibility of copies of organization certificates of national bank associations. U. S. REv. STat. $\$ 886$ (1878), 28 U. S. C. A. $\$ 665$ (1926), admissibility of transcripts from books of the Treasury: in suits against delinquents. U. S. REv. SrAr. $\S 887$ (1878), 28 U. S. C. A. $\$ 668$ (1926), same: in trials of indictments for embezzlement of public moneys. U. S. REv. STAT. $\$ 888$ (1878), 28 U. S. C. A. $\S 669$ (1926), admissibility of copies: of returns in returns office in prosecution for false return. U. S. REv. STAT. $\S 889$ (1878), 28 U. S. C. A. $\S 671$ (1926), same: of post office records and statements of accounts. U. S. REV. STAT. $\S 890$ (1878), 28 U. S. C. A. $\S 670$ (1926), same: of statements of demands by the Post Office Department in suits against postmasters. U. S. Rev. Stat. $\$ 891$ (1878), 28 U. S. C. A. $\$ 672$ (1926), same: of records of the General Land Office. U. S. REv. STAT. $\$ 892$ (1878), 28 U. S. C. A. $\$ 673$ (1926), same: of records, etc. of the Patent Office. U. S. REv. Srat. \& 894 (1878), 28 U. S. C. A. \& 675 (1926), same: of specifications and drawings of patents. U. S. Rev. STar. \& 895 (1878), 28 U. S. C. A. $\S 676$ (1926), admissibility of extracts from the Journals of Congress. U. S. Rev. Stat. $\$ 896$ (1878), 28 U. S. C. A. $\S 677$ (1926), admissibility of copieg of records in offices of United States consuls. 27 STar. 273 (1892), 25 U. S. C. A. $\$ 6$ (1926), 
of proving certain public records only in limited types of cases. ${ }^{93}$

The proof of marriage statutes are heterogeneous. To be entitled to receive a pension, the widow of a colored or Indian soldier or sailor need only prove a ceremony deemed obligatory, or habitual recognition of each other as man and wife, together with recognition of that relationship by their neighbors up to the time of enlistment or death; ${ }^{01}$ any other widow must prove a marriage which is legal according to the place of residence at the time of marriage or at the time when the right to a pension accrued. ${ }^{05}$ The claimant to war risk insurance must prove marriage by such testimony as the Director of Veterans' Affairs prescribes. ${ }^{90}$ Under the Indian Act, marriage of a white man to an Indian woman may be proved by admission, general repute, cohabitation as married persons, or other circumstantial or presumptive evidence. ${ }^{97}$

II

\section{Scope of the Rule-Making Power}

Reform of the federal rules of evidence seems necessary. What steps can be taken? One writer felt that, "If Congress would provide a code of evidence and keep it modernized, a Utopian ideal would be realized." However, he concluded that "Congress has never shown any symptoms of willingness to consider these matters seriously and probably should devote its time to broader aspects of national affairs." ${ }^{\text {m8 }}$ But while Congress has not enacted a code of evidence, it nevertheless seems that it has, by the new rule-making act, conferred the power upon the Court to deal with the problem. ${ }^{99}$ However, some doubt, as to whether the Act includes the law of evidence, has been suggested by a combination of two facts: (1) the provision in the Act providing that said law rules "Shall neither

admissibility of copies of records: from office of Commissioner of Indian Affairs. 34 Srar. 606 (1906), \& U. S. C. A. § 356 (1926), same: required under the naturalization las. 36 STAT. 555 (1910), 49 U. S. C. A. \& 16 (13) (1926), admissibility of copies of schcdules, tariffs, contracts, etc. kept as public records under the Interstate Commerce Act.

93. Thus, in suits against postmasters, copies of statements of demands by the post office department are admissible. U. S. REv. STAT. $\$ 890$, supra note 92 ; and sqe U. S. REv. STAT. $\$ \S 886,887,888$, all supra note 92.

94. 17 Stat. 570 (1873), 38 U. S. C. A. $\S 198$ (1926); United States v. Route, 33 Fed. 246 (D. Mo. 1887).

95. 22 Star. 345 (1882), 38 U. S. C. A. \& 199 (1926); United States v. Hays, 20 Fed. 710 (C. C. Mo. 1884).

96. 43 Stat. 613 (1924), 38 U. S. C. A. $\S 446$ (1926), as amended 46 Star. 1016 (1930), 38 U. S. C. A. $\$ 446$ (Supp. 1935).

97. 25 STAт. 392 (1888), 25 U. S. C. A. § 183 (1926).

98. Leach, State Law of Evidence in the Federal Cottrls (1930) 43 Hrav. L. REv. 554, 583 ; also see id., at 567 .

99. The present act confers power to make rules governing "practice and procedure." 48 STat. § 1054 (1934) 28 U. S. C. A. $\$ 723$ b (Supp. 1935). 
abridge, enlarge, nor modify the substantive rights of any litigant;"100 and (2) the general but not universal tendency in the past to regard evidence as falling within Section 34 of the original Judiciary Act, commonly known as the Rules of Decisions Act ${ }^{101}$ - a statute which has always been regarded as governing substantive and not procedural rights. ${ }^{102}$

Despite, however, this technique of using a substantive-right statute to secure conformity to the state law of evidence, it is believed that rules of evidence should be considered within the domain of procedural law. The Supreme Court has recognized the principle that many rules of evidence are procedural. Thus, in equity it has refused to apply a state statutory rule of evidence. ${ }^{103}$ And a New York statute in force in 1872 was held applicable under Section 916 of the Revised Statutes, ${ }^{104}$ thus enabling examination of a judgment debtor concerning his property. Although the debtor contended that the proceedings in their origin and nature are of equitable jurisdiction exclusively, which, by the prohibition of the Constitution, Congress cannot lawfully authorize the courts of the United States to administer except by bill in chancery, the Court held that the matter of examination was a "mere matter of procedure, not involving the substance of any equitable right, and may be located, by legislative authority, to meet the requirements of judicial convenience."105 If this method of eliciting the truth concerning the facts, subsequent to

100. It has, however, been suggested that, although a rule-making act should expressly include or exclude evidence, the act (then the proposed act) probably was intended to include evidence, "since the only express limitation is that 'said.rules shall neither abridge, enlarge, nor modify the substantive rights of any litigant.'" SweENEY, Federal OR STATE Rules of Evidence in Federal Courts (1932) 394, 398. See § 4551, reprinted in Sey. REP. No. 892, 64th Cong., 2d Sess. (1917), which expressly included in the grant the matter "of taking and obtaining evidence." This bill, the predecessor to the present act, was reported favorably by Senator Sutherland, now Justice Sutherland.

101. Supra note 6 . "It has always been construed as applying to the law of evidence." Leach, supra note 98, at 567. McNiel v. Holbrook, 37 U. S. 84 (1838); Ryan v. Bindloy, 68 U. S. 66 (1863) ; Conn. Mutual Life Ins. Co. v. Union Trust Co., 112 U. S. 250 (1884); Ex parte Fisk, 113 U. S. 713 (1885); Nashua Savings Bank v. Anglo-American Co., 189 U. S. 221 (1903).

102. Wayman v. Southard, 23 U. S. 1 (1825).

103. Dravo v. Fabel, 132 U. S. 487 (1889). If the statutory rule had been one of substantive law it would have been followed, not by virtue of the Rules of Decisions Act, since that is limited to common law cases, but because of a principle of law of which that act is only partially declarative. Mason v. United States, 260 U. S. 545 (1923).

104. "The party recovering a judgment in any common law cause in any district court, shall be entitled to similar remedies upon the same, by execution or otherwise, to reach the property of the judgment debtor, as were provided on June 1, 1872 in like causes by the laws of the State in which such court is held, or by any such laws which may subscquently be enacted and adopted by general rules of such district court; and such courts may, from time to time, by general rules, adopt such state laws as may be in force in such state in relation to remedies upon judgments, as aforesaid, by execution or otherwise."

105. Ex parte Boyd, 105 U. S. 647, 658 (1881). 
trial though it may be, is a matter of procedure, then the method of eliciting the facts, prior to or at trial, may well be considered within the same category.

Many other instances may be found where evidence and procedure have been identified. ${ }^{106}$ The American Law Institute classifies rules of evidence as procedural in nature, and specifically deals with "proof", "presumptions and inferences", "competency and credibility", and "admissibility" in a chapter entitled "Procedure". ${ }^{107}$ In 1905, the Illinois legislature passed an act creating the Municipal Court of Chicago and providing for its jurisdiction and practice. ${ }^{108}$ A rule-making power was granted in these terms:

"Sec. 20. (Rules of practice, how adopted). That the judges of said municipal court shall have power to adopt, in addition to or in lieu of the provisions herein contained prescribing the practice in said municipal court, or of any portion of said provisions, such rules regulating the practice in said court as they may deem necessary or expedient for the proper administration of justice in said court." ${ }^{\text {"109 }}$

In a note commenting upon the meaning of the term "practice" as used in this section, it is said:

"There was at one time a difference of opinion among the members of the Supreme Court as to what was included in 'practice'. Three members of the Court were of the opinion that it had a narrower meaning than 'procedure' and that it did not include 'evidence' or judicial notice, but the majority of the Court held the contrary and that under the Constitutional Amendment of 1904 the legislature was authorized to create a municipal court in and for the city of Chicago and to prescribe the jurisdiction, practice, and procedure in the court and that included in that were rules of evidence."110

Acting under that decision the Municipal Court of Chicago adopted a rule applying the rules of evidence in force in the state circuit courts, except as otherwise provided by its own rules. ${ }^{111}$ Here is an instance in which

106. That a statute firing a rule of evidence regarding disputed handwriting is one "merely regulating procedure," see Thompson v. Missouri, 171 U. S. 380, 385, 385 (1897).

That a statute shifting burden of proof of contributory negligence operates "only" as a change in procedure," see Sackheim v. Pigueron, 215 N. Y. 62, 73, 109 N. E. 109, 112 (1915). "Legislative usage has firmly established this view of the scope of procedure. Following the example of the Field Code in New York, it has become almost uniform Ameriean practice to place statutory rules of evidence, with the rules of pleading and practice, as a part of the code of civil procedure." Sunderland, Character and Extent of the RuleMaking Power Granted U. S. Supreme Court and Methods of Effective Excreise (1935; 21 A. B. A. J. 404, 406-407.

107. See Restateatent, Conflict of Laws (1934) \$\$ 5\$5, 595-59S.

108. Civil Practice Rules of the Munictpal Court of Cmacigo (1933) 205.

109. Id. at 222 .

110. Id. at 225. The case referred to in the comment is Chicago v. Williams, 254 III 360,98 N. E. 666 (1912).

111. Supra note 108, at 133. 
a rule-making act, much less inclusive than the new federal procedure act, which covers both practice and procedure, is construed to embrace rules of evidence.

It would seem that the Supreme Court has ample authority to prescribe rules of evidence, should it be deemed desirable. ${ }^{112}$

\section{III}

\section{CONFORMTTY VS. UNIFORMITY}

Conformity in evidence today is only an approximation. There is a decided drift toward uniformity where the field has not been preempted by statute. ${ }^{113}$ Which should be the goal? Something is to be said in favor of either, and certainly either would be preferable to the present hodge-podge with its resultant uncertainty.

For the judges of the federal district courts, there can be no doubt that uniformity rather than conformity is to be preferred. As one writer has pointed out, it is customary to assign such judges temporarily to judicial districts in states remote from their homes, where their services may be needed because of a congestion of the dockets of the federal courts in those districts; and a mandate to follow the state rules of evidence imposes a very real burden upon such judges and greatly impairs their efficiency in the conduct of trials. ${ }^{114}$ It has been argued that the hardship worked upon the federal judge is no greater than the hardship placed on the bar by an absence of conformity, but is probably less, in that counsel have the duty of informing the court on matters peculiar to their state law. ${ }^{115}$ The counter-argument is that the judge must have a working knowledge of the laws of evidence in order that trials may be expedited; that counsel's duty to inform the court on the state law properly applies to the pivotal substantive matters of the litigation, and not to the incidentals, such as evidence.

To the lawyer who has a casual federal practice, strict conformity to state evidence would undoubtedly be a great boon, unless uniform rules were made simple and easy of application. It would free him from the necessity of mastering two systems of evidence. On the other hand,

112. See Sunderland, supra note 106 , at 407 ; cf. Wickes, infra note 113 , at $23-25$, whero he suggests that Congress could not have intended the repeal of the Rules of Decisions Act by the grant or exercise of rule-making power, and hence could not have intended that such power extend to the field of evidence.

113. Wickes, The New Rule-making Power of the United States Supreme Court (1934) 13 Tex. L. REv. 1, 19, 22.

114. Id. at 14, 19; Chicago \& N. W. Ry. Co. v. Kendall, 167 Fed. 62, 70 (C. C. A. 8th, 1909).

115. Leach, State Law of Evidence in the Federal Courts (1930) 43 HARv. L. Rev. 554, 584. 
however, uniform rules would lighten the task of the specialist in federal practice in conducting litigation in more than one federal district. ${ }^{11 B}$

Arguments pro and con based on the convenience of judges and practitioners are entitled to consideration, but are by no means of controlling importance. Members of the bar quite unanimously supported the passage of the act under which a uniform federal procedure is being worked out, despite whatever advantage a strict conformity to state practice might bring them. It was felt that better administration of justice would be possible, and this was regarded as of primary importance. ${ }^{117}$ This feature of administration deserves further consideration, because here, too, there are factors both for and against uniformity.

Against uniformity, it can be said that two procedural systems create instances in which one result is obtainable in a state court and another in a federal court sitting in the same state. ${ }^{118}$ The burden upon the lawyers, about which we have spoken, also increases procedural hazards, impairing the efficiency of the court; "this hardship, for which the public ultimately pays, is quite independent of the merits of the rules followed in either tribunal. The mere fact of difference is itself a serious impediment, multiplying the procedural technicalities which constitute the chief cause of popular dissatisfaction with the courts."110 There is often a very close judicial relation between legal rights and the evidence which will establish them. Presumptions and burden of proof, suits involving title to land, are commonly used examples. It can be urged that conformity would operate to give full force and effect to local remedies and modes of rendering substantive rights cognizable. ${ }^{120}$ And so far as cases of exclusive federal jurisdiction are concerned, conformity has been said to be desirable in that the federal court will have the benefit of advanced state legislation. ${ }^{121}$

The proponents of conformity, however, rely mainly on the argument that substantive rights are better enforced through state rules of evidence. But in the forty-eight states may be found as many systems of evidence, some usefully serving their purpose, and others not. Conformity in the first class should result in effective administration of justice; but, in the latter it would merely thwart the proper investigation of the facts. The advantages of the first group can be attained for all federal districts

116. Wickes, supra note 113 , at $14,19$.

117. (1912-1915) 37-40 A. B. A. REP.; (1921-1929) 46-54 A. B. A. REP. (Reports of the Special Committee on Uniform Judicial Procedure).

118. Leach, supra note 115 at 582; cf. Tidal Oil Co. v. Flanagan, 263 U. S. 444 (1924), with Kuhn v. Fairmont Coal Co., 215 U. S. 349 (1910). See F. W. Woolworth \& Co. v. Wilson, 74 F. (2d) 439 (C. C. A. 5th, 1934).

119. Sunderland, The Grant of Rule-making Pouter to the Supreme Court of the United

States (1934) 32 MitcH. L. REv. 1116, 1121.

120. See Dobie on Federal Procedure (1928) 628-630.

121. Leach, supra note 115 , at 583 . 
through uniform rules of evidence adopting the better principles worked out by state legislation and decisions. Further, the advantages to be derived from national consistency cannot be laid aside lightly. This is particularly true as to the federal specialties of bankruptcy and patents. ${ }^{122}$ Aside from the specialties, the volume of business transacted in the federal courts is large, and the cases there pending are usually of considerable magnitude and importance, not only because of the amounts involved, but in the effect of their determination upon future policies having interstate and often national scope. ${ }^{123}$ Opinion that "federal litigation is sufficiently important to warrant the taking of steps for its reform as a whole" is crystallizing. ${ }^{124} \mathrm{Mr}$. Wigmore says:

"The truth is that the time seems to have come, for the rules of evidence as for procedure in general, when the pristine principle of conformity must be abandoned in the practice of the Federal Courts. It is more important, under modern conditions, that Federal practice all over the Nation should be uniformly consistent with itself than that it should, by varying, conform chameleonlike to local State practice. A general re-casting of the Federal rules of Evidence is therefore to be expected whenever the principle of Federal uniformity finds full acceptance in legislation and in rules of Court."125

Under the new statute, there is to be general federal uniformity in the practice and procedure governing all civil cases at law and in equity. One effect may be that in some cases a different result will be reached in a federal court than in the state court. But if the new federal procedure is simple and non-technical, it is submitted that the result is apt to be a closer approximation to satisfactory administration of justice. The same assumption can be made relative to decisions turning on points of evidence, if rules thereon are promulgated.

And the evils which the proponents of conformity fear may very well disappear through the states' gradual acceptance of the federal system as their model. This was the belief and hope of the proponents of the new rules of procedure. ${ }^{126}$ One writer suggests that "there are serious con-

122. Id. at 583 ; Sweeney, supra note 100 , at 399.

123. Wickes, supra note 113 , at 13 . From a study of the business in thirteen districts for the year ending June 30,1930, it appeared that about three-fifths of the civil litigation in the federal courts consists of government cases, about one-fifth deals with federal questions, and about one-fifth is based on diversity of citizenship. In over two-thirds the diversity cases, one or both of the parties was a private forcign corporation. It is significant that approximately four-fifths of the civil litigation in the federal courts is of truly national character. It is also safe to say that many of the cases in the remaining one-fifth have an indirect but positive effect upon corporate interstate business policy. Sec American Law Institute, $A$ Study of the Business of the Federal Courts (1934) Part II, 48-49, 99.

124. Wickes, supra note 113 , at 13 .

125. Wigmore, Select Cases on Evidence (3d ed. 1932) 1020.

126. (1925) 50 A. B. A. ReP. 549; (1926) 51 A. B. A. Rep. 515 ; (1928) 53 A. B. A. ReP. 510. 
siderations militating against such an outcome," in that the states will quite likely wish to keep the control of the processes of their courts in their own hands, and that should there be such adoption, the initiative in judicial reform would pass to Washington, weakening the vitality of state jurisprudence. ${ }^{127}$ Without concrete evidence one way or the other, a valid prediction is difficult; but it is submitted that if the federal procedure is as successful in operation as it might well be, the pressure of the people and bar in the state will be brought to bear upon its adoption, rather than toward a jealous guarding of procedural independence; that it is a matter of conjecture whether state initiative in reform will cease upon an adoption of the federal procedure. It is more probable that the Supreme Court and the bodies engaged in judicial reform in the various states will cooperate in a study of the working of the system with a view to its improvement.

\section{IV}

\section{The Problem of Federal Rules}

If, then, uniform rules of evidence for the federal courts are desirable (and we submit that they are), the immediate problem concerns their style and character. Since we cling tenaciously to the common-law right of jury trial, we should be willing to dignify the jury to the extent of adopting rules of evidence which will permit all reliable and pertinent information to be laid before them, subject, of course, to the court's tempering comment on the evidence. This power of the federal judge to comment on the evidence after argument of counsel and before its submission to the jury should not be overlooked. It is a power not possessed by judges of many states, ${ }^{128}$ and one that warrants the relaxation of many state rules which may be defensible because of the absence of such power. Bearing this in mind, if we give to the trial judge a large discretion in deciding what evidence is sufficiently trustworthy to be considered, most of the terminology of rigid rules, often relaxed or circumvented in practice, may be discarded without any serious consequences. ${ }^{129}$ The history of evidence is a history of relaxation, a movement toward inclusion and away from exclusion, as one by one the bogies of fraud and perjury have been exposed. This trend should be continued. ${ }^{130}$

127. Sunderland, supra note 119, at 1125-1127.

128. 2 Hyatt on Trtats (1924) 1073; Morgan axd ormers, TuE Liw of Eviderce (1927) 9.

129. See Sunderland, supro note 106 , at 407.

130. Thus the disqualifications of parties as witnesees because of interest has disappeared. 1 Wigarore oN EvIDENCE (1923) §§ 575-577. The statutes excluding the testimony of a survivor of a transaction with a decedent are being subjected to severe criticism. TArT, Liv Reforar (1926) 79; see Morgan, op. cit. supro note 128, at 23-49. 
A detailed code of evidence is impracticable and undesirable; ${ }^{131}$ given a few carefully drafted rules, flexible and broad in character, the courts can be left to fill in the interstices. The federal statutes on mode of proof should be modernized along lines suggested by advanced and prevalent state legislation. ${ }^{132}$ The statutes on proof of records should be harmonized and expanded, ${ }^{133}$ the proof of business and other routine records facilitated and put in line with the principles upon which the commercial world proceeds. ${ }^{134}$ General rules on hearsay should be recorrelated to today's notions of reliability, ${ }^{135}$ and exclusionary rules of competency and privilege revalued. ${ }^{136}$ The concept of judicial notice might be expanded to avoid the necessities and uncertainties of proof in many situations. ${ }^{137}$ Of course, as experience warrants, new rules may be added, or old ones modified. The task can never be laid aside as completely done; but it is an undertaking which is clearly needed.

131. See 1 Wigmore, Evidence (1904) 30. Experience with codes which are intended to regulate in detail has shown that they are subject to a mushroom growth of amendments and additions, becoming more and more complex and confusing, until a revision is necessaryand then the process begins all over again. See (1930) 55 A. B. A. REP. 528 (Report of the Special Committee on Uniform Judicial Procedure.

132. See Mass. Gen. Laws (1932) c. 231, $\$ \$ 61-69$, c. 233; Mrca. Cons. Laws (1929) $\S \S 13543-13549,14160-14169$; Pa. Stat. ANN. (Purdon, 1930) tit. 28, $\$ \S 1-9,31-33,61-63$.

133. Sucpra p. 640.

134. See Morgan, supra note 128, at 51-63.

135. See 1 WigMore on EvtDence (1923) 136-139, \& 8a.

, 136. Id. at $133-135 ; 5$ id. $\$ \S 2291,2380$; JoNES, EVIDENCE (1924) $\$ \S 748,759$.

137. See 5 WIGMORE, §§ 2583. 